\author{
JULY 2016, VOLUME 4, ISSUE 3, 13 - 36 \\ E-ISSN NO: $2289-4489$
}

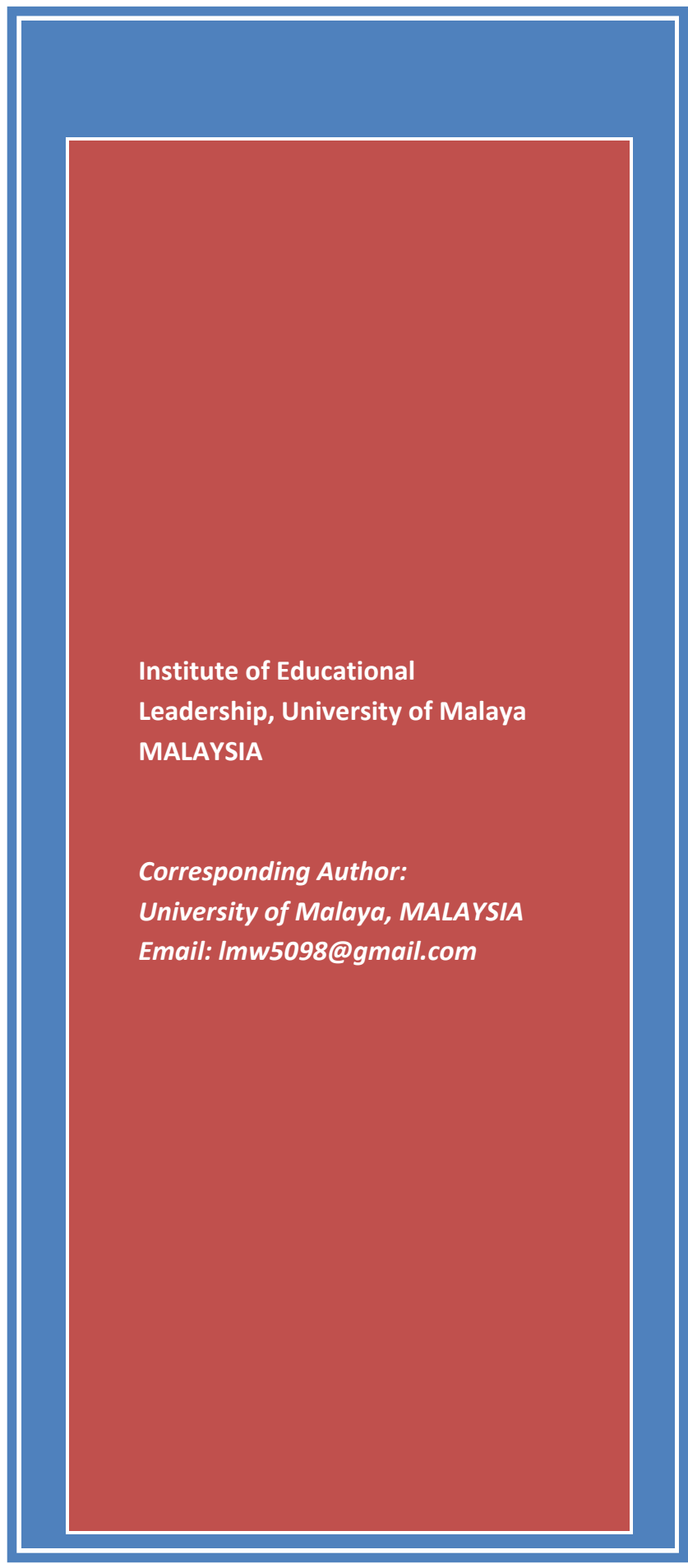

\title{
RELATIONSHIP BETWEEN PRINCIPAL TECHNOLOGY LEADERSHIP PRACTICES AND TEACHER ICT COMPETENCY
}

Leong Mei Wei, Chua Yan Piaw (PhD), Sathiamoorthy Kannan (PhD)

\begin{abstract}
This study aims at examining the relationship between principal technology leadership practices and teacher ICT competency in Negeri Sembilan secondary schools in Malaysia. This is a non-experimental quantitative research using survey technique through the administration of a set of questionnaires on teacher demographic variables, principal technology leadership practices and teacher ICT competency. Some 417 returned questionnaires have been analyzed. The findings showed that teachers in Negeri Sembilan secondary schools perceived that their principals have high level of technology leadership and they also rated themselves as having high level of ICT competency. Furthermore, data indicated a statistically significant positive and moderately strong correlation between principal technology leadership practices and teacher ICT competency. In addition, the multiple regression analysis showed that digital citizenship and systemic improvement are the two principal technology leadership practice dimensions that are statistically significant predictors of teacher ICT competency. The fitness indices of the proposed structural model do not achieve the level of fitness required for RMSEA (Root Mean Square of Error Approximation), GFI (Goodness of Fit Index), and Ratio Chisq/df (Chi-square/ Degrees of Freedom). Thus, a re-specified structural model was established for this study.
\end{abstract}

Keywords: Technology Leadership, Teacher ICT Competency, Principals, Education, Malaysia. 


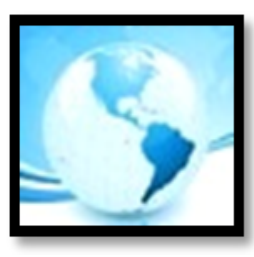

\section{MALAYSIAN ONLINE JOURNAL OF EDUCATIONAL MANAGEMENT (MOJEM)}

\section{INTRODUCTION}

Globalization together with the information and communications technology (ICT) advancement have created a new knowledge-driven economy era and competitiveness in the workplace (Haughey, 2006).Governments around the world have begun to allocate huge amounts on ICT to address the demands of this digital information age (Ministry of Education Malaysia, 2010). Avci Yucel and Gulbahar (2013) noticed that the progress of web-based technology together with the exponential growth in internet accessibility has enabled widespread usage of webbased applications across many different disciplines. Furthermore, Adeyemi and Olaleye (2010) found that ICT plays an important role in advancing knowledge and is the essential skill for effective functioning in the modern world(Trilling \& Fadel, 2009). Hence, an educated ICT literate workforce is vital to remain competitive (Ministry of Education Malaysia, 2013).

Educational technology has transformed the educational (Wong, Mas Nida, Abu Daud, \& Othman, 2011) and instructional landscape (Papa, 2011). To accelerate entry into this Information Age, the Malaysian government launched the Multimedia Super Corridor (MSC) in 1996 to turn Malaysia into a fully developed country and knowledge-based society by 2020 with the advancement in ICT. Smart Schools, one of the seven flagships under the MSC aimed at integrating ICT into instructional processes and school management to adequately prepare the e-generation for the competitive globalized world (Hamsha, 2011). Now, the new concept of 'ICT in Education' includes a greater scheme by blending multi-lateral efforts from all stake holders to solidify the appropriate approach of integrating ICT in education (Ministry of Education Malaysia, 2010). Furthermore, MSC Malaysia would identify and support development of niche areas in e-solutions and software, shared services, creative multimedia, outsourcing and e-business in the 10th Malaysia Plan 2011-2015 (Economic Planning Unit of Prime Minister's Department, 2010).

Moreover, the Interim Strategic Plan 2011-2020 (Ministry of Education Malaysia, 2012b), also strongly emphasized ICT usage in the instructional process as well as in administration and management of schools and educational institutions as a precondition for Malaysia to become a high-income nation to achieve the 10th Malaysia Plan 2011-2015 objectives. The MOE has launched a new National Education Blueprint in October 2011 (Ministry of Education Malaysia, 2012a) which offers a vision of the educational system and students' aspirations that Malaysia both needs and deserves, and 11 operational shifts or strategic initiatives have been suggested to achieve the mentioned vision. Among these 11 strategic thrusts, shift seven is related to leveraging ICT to enhance the quality of learning across the whole country by providing a Virtual Learning Environment (VLE) via 1-BestariNet and internet access for all schools. Furthermore, Clause 29 and 30 in the National Education Policy effort from the Educational Policy Planning and Research Division (2012) also clearly reflected the needs of the educational system in Malaysia to integrate ICT into the instructional process and educational management.

Since educational technology has become increasingly vital in today's modern information explosion environment and principals with efficient technology leadership skills are the key to successful technology integration plans and policies (Bolman, 2012; Norazah, Yusma, \& Kamaruzaman, 2010), the evaluation and further exploration of principals' technology leadership is needed because this could help to better prepare current and future leaders to implement the technology integration policy successfully(Chang, Chin, \& Hsu, 2008). Flanagan and Jacobsen (2003) stated that achieving successful technology integration in schools will require leadership goals, competencies and responsibilities. Technology has emerged as a major factor in leadership development; preparation programs will reshape how educational leaders learn, interact, and conceptualize their professional technological practices (Webber, 2003). 


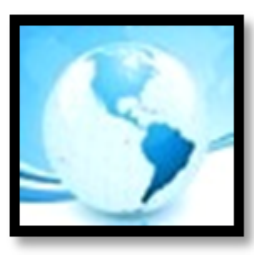

\section{MALAYSIAN ONLINE JOURNAL OF EDUCATIONAL MANAGEMENT (MOJEM)}

Furthermore, LaFrance and Beck (2014) found that field-based learning experience and authentic courses are necessary for leadership preparation programs. They suggested that future principals should begin mentoring and internships activities in the early stage of the program and should be engaged in a real-world setting to prepare them to lead in an increasingly advanced technological world. As technologies became increasingly important in the educational system, school principals need improved understanding to better respond to technological changes (Richardson, Bathon, Flora, \& Lewis, 2012); hence they need the necessary training to help them in performing their role as technology leaders.

\section{PROBLEM STATEMENT}

Recently, the Malaysian education system received criticism and public scrutiny from parents as well as employers, who voiced their concern regarding whether our education system is able to adequately prepare Malaysian students for the upcoming challenges of the 21st century. Furthermore, the Malaysian government has invested much in education since independence (Ministry of Education Malaysia, 2012a), but the gap between the high levels of expenditure on educational technology and the expected return in school improvement is still a global education agenda subject to great debate (Leong, 2010; Lu, 2013; Wahdain \& Ahmad, 2014).

Besides, continuous efforts are being carried out to enhance Malaysian teacher ICT skills (Sathiamoorthy, Leong, \& Mohd Jamil, 2011), but the ICT usage in schools lags behind expectations in terms of quantity and quality (Fong, Ch'ng, \& Por, 2013). This indicates that the investment and policies in getting teachers to embed ICT use in education have not been found helpful by teachers (Haydn \& Barton, 2008).

Chen (2004) and Wachira and Keengwe (2011) found that despite the proliferation of computer equipment in schools and the promise of educational technology, survey of teachers consistently showed decline in educational technology usage. Based on a MOE study finding in 2010, only 33\% of students are aware that their teachers are using ICT regularly in their teaching process even though ICT has tremendous potential to accelerate the instructional process; clearly, this potential has not yet been achieved (Ministry of Education Malaysia, 2012a).

Furthermore, based on the Feedback on The Auditor General's Report 2013, Series 3 (Ministry of Finance, 2014), the level of Virtual Learning Environment (VLE) usage among Malaysian teachers is very low (in the range of $0.57 \%$ to $4.69 \%$ ). This issue of low and slow uptake of technology among teachers brings us to one very pertinent question: What can be done to ensure that teachers do and want to accept and use technology in carrying out their routine duties as teachers? Hence, a paradigm shift is needed in the minds of the school principals, the teachers and the relevant authority in charge of preparing principals and teachers, to maximize the potential of ICT and its application, to keep abreast of rapid technology development (Sathiamoorthy et al., 2011).

Even though ICT usage has been proven able to improve effectiveness and productivity of many organizations, the human factor is identified as the most important determinant of success or failure of ICT implementation (Wahdain \& Ahmad, 2014). According to Liew (2007), most teachers may not be in favour of ICT programs because they lack competency in dealing with ICT. Is this the main cause of low level ICT usage among teachers? According to Hamsha (2011), adopting ICT competency standards and adequate training will help school leaders and teachers to incorporate ICT effectively in education. Besides, it is also commonly acknowledged that ICT is expanding rapidly; if teachers are not ready with adequate and latest knowledge and skills, they would not be able to keep pace with the ever-changing technology and inevitably will be left behind and unable to master new ICT competencies (Mas Nida, Wong, \& Ayub, 2011). So, in order to prepare teachers to use technology effectively, we need to investigate the current level of teacher ICT competency; in other words, how teachers perceived their own ICT competency. 
Teachers have been acknowledged as the catalyst to achieve the assurance of educational technology; overlooked in the implementation process was that attaining to this assurance depended fundamentally on principals. Principals play the most critical role in making policymakers' visions for ICT integration and usage a reality at all levels. However, most of the previous studies have not pointed out how principals function as the key agents in influencing other users in ICT integration and usage (Levin \& Datnow, 2012). It is generally agreed that leadership has an important effect on teacher ICT application, but to date, relatively little empirical study has explored this phenomenon in detail (Neufeld, Dong, \& Higgins, 2007).

Although the principal is the key in leading ICT implementation in schools, according to Rossafri and Balakrishnan (2007), most of the principals were at a low level of skills and knowledge related to ICT and they were uncomfortable being leaders in the technology field, or they may be unsure about the effectiveness of technology leadership in school improvement. Besides, not many school principals are aware that the Ministry of Education (MOE) has made a huge investment in reducing the digital gaps in the education system today. This causes them to neglect their responsibility as technology leaders which is probably one of the contributing factors to the failure of technology implementation in education. Are the school principals providing sufficient technology leadership to enhance teachers' ICT competency for ICT applications? Does the biggest barrier to technology implementation lie in principals' technology leadership? The main question that arises here is whether school principals demonstrate sufficient technology leadership practices.

According to Sathiamoorthy et al. (2011), when principals recognize their role in technology leadership, they can easily provide at least 30\% change and enhancement in teachers' ICT skill. If the principals become more aware of the various dimensions of technology leadership along which they can contribute, they can then do more for their teachers' ICT skill development. In other words, only when school principals are ready for their emerging role as technology leaders will teachers be positively influenced and supported to accept technology integration.

The issue of principal role as technology leader is beginning to raise some concerns in Malaysia. However, these principals are not conscious of their role as technology leaders and practically doing nothing about it (Sathiamoorthy, Sailesh, \& Zuraidah, 2012). Wilmore and Betz (2000) found that limited research has been conducted on the principal's role in ICT implementation in schools. Malaysia, being a developing country, is lagging behind the developed ones in terms of the number of studies on this issue (Sathiamoorthy et al., 2011). Thus, based on the problems stated, the researcher aims at investigating the relationship between the principal technology leadership practices and teacher ICT competency in Negeri Sembilan secondary schools.

\section{RESEARCH OBJECTIVES}

This study aims at investigating teachers' perception of the level of principal technology leadership practices and teacher ICT competency in Negeri Sembilan secondary schools. The objectives of this study are as follows:

(a) To analyze the level of teacher ICT competency in Negeri Sembilan secondary schools.

(b) To analyze the level of principal technology leadership practices in Negeri Sembilan secondary schools.

(c) To examine the relationship between principal technology leadership practices and teacher ICT competency in Negeri Sembilan secondary schools.

(d) To analyze which of the principal technology leadership practices dimensions are the significant predictors of teacher ICT competency in Negeri Sembilan secondary schools.

(e) To evaluate if the proposed structural model involving principal technology leadership practices and teacher ICT competency fit with the data collected from Negeri Sembilan secondary schools. 


\section{CONCEPTUAL FRAMEWORK}

This study investigates teacher ICT competency as the endogenous (dependent) variable in relation to principal technology leadership practices as the exogenous (independent) variable. Generally, the conceptual framework for this study was based on various leadership theories (Bass \& Bass, 2008; Bush, 2011; Leithwood \& Jantzi, 2006; Northouse, 2013; Owens \& Valesky, 2007; Robbin \& Judge, 2013; Yukl, 2013) underscoring that leadership is a process of influence through social interaction. Specifically, the researcher found that the three broad clusters of transformational leadership practices in Leithwood and Jantzi's model (2006) are very similar to the five dimensions of principal technology leadership practices (i.e., visionary leadership, digital age learning culture, excellence in professional practice, systemic improvement, and digital citizenship) which is used as the exogenous variable in this study. This transformational theory was used to study the effects of leader behavior on follower's satisfaction, performance, commitment, and motivation. This theory indicates that transformational leaders engage the aspirations of followers, energize their emotional and mental resources, tap their inner motivations, and involve them enthusiastically in the work to be done.

Furthermore, the main focus of House's $(1971,1996)$ path-goal leadership theory is to enhance follower's performance and satisfaction through motivation. Thus, the leader needs to provide support in terms of the necessary skills and competence to their subordinates for work-goal attainment (Northouse, 2013). Hence, as applied to this study, these leadership theories (transformational and path-goal) hold that the principal technology leadership practices will influence teacher ICT competency because very often, the teachers are found to be relating their performance to the principals' leadership of their schools. When teachers perceive good leadership from their principals, they seem to be actively involved in all the programs developed or implemented by the principal (Sathiamoorthy et al., 2012).

Based on empirical studies conducted by Harin Hafian (2011) and Moktar (2011), it was found that principal technology leadership practices do have some impact on teacher ICT competency but there is still lack of empirical evidence to show the strength of the relationship. Thus this study was carried out to examine the relationship between principal technology leadership practices and teacher ICT competency in Negeri Sembilan secondary schools. The conceptual framework of the study is shown in Figure 1.

\begin{tabular}{|c|c|}
\hline $\begin{array}{l}\text { EXOGENEOUS VARIABLE } \\
\text { Principal Technology Leadership Practices: } \\
\underline{\text { (ISTE Standard. A, 2009) }} \\
\text { 1. Visionary leadership } \\
\text { 2. Digital age learning culture } \\
\text { 3. Excellence in professional practice } \\
\text { 4. Systemic improvement } \\
\text { 5. Digital citizenship }\end{array}$ & 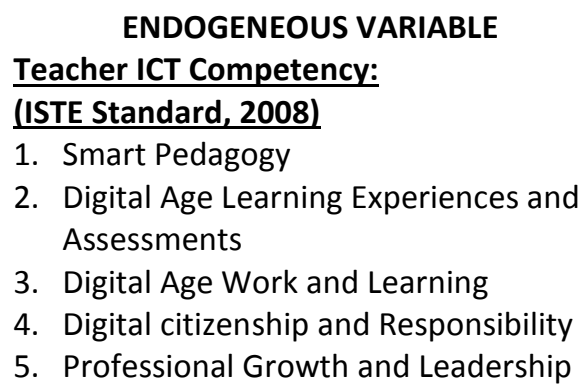 \\
\hline
\end{tabular}

Figure 1. Conceptual framework of the study (Source: ISTE Standards •T, (2008) ; ISTE Standards •A, (2009) 
In this framework, the endogenous variable, teacher ICT competency comprised five dimensions according to ISTE Standards $\bullet T(2008)$. Each of these five dimensions is operationally defined as follow:

1. Smart Pedagogy: teachers' ability to use their knowledge of pedagogical, instructional, and technology to facilitate experiences that advance student creativity, innovation and learning in virtual environments.

2. Digital Age Learning Experiences and Assessments: teachers' ability to develop, design, and evaluate authentic learning experiences and assessments incorporating contemporary resources and tools to maximize content learning in context.

3. Digital Age Work and Learning: teachers' ability to exhibit skills, knowledge, and work processes representative of an innovative professional in a global and digital society.

4. Digital citizenship and Responsibility: teachers' ability to understand local and global societal issues and responsibilities in an evolving digital culture and exhibit legal and ethical behavior in their professional practices.

5. Professional Growth and Leadership :teachers' ability to model lifelong learning, continuously improve their professional practice, and exhibit leadership in their school and professional community by promoting and demonstrating the effective use of digital tools and resources.

The exogenous variable, principal technology leadership practices comprised five dimensions according to the ISTE Standards $\bullet A(2009)$. Each of these five dimensions is operationally defined as follow:

1. Visionary leadership is defined as whether teachers perceive that their principal is able to inspire and lead the development and implementation of a shared vision for comprehensive integration of information technology to promote excellence and support transformation throughout the school.

2. Digital age learning culture is defined as whether teachers perceive that their principal is able to create, promote, and sustain a dynamic, digital-age learning culture that provides a rigorous, relevant, and engaging education for all students.

3. Excellence in professional practice is defined as whether teachers perceive that their principal is able to promote an environment of professional learning and innovation that empower educators to enhance student learning through the infusion of contemporary technologies and digital resources.

4. Systemic improvement is defined as whether teachers perceive that their principal is able to provide digital age leadership and management to continuously improve the school through the effective use of information technology resources.

5. Digital citizenship is defined as whether teachers perceive that their principal is able to model and facilitate understanding of social, ethical and legal issues and responsibilities related to an evolving digital culture among community members.

\section{METHODOLOGY}

\section{Research Design}

This study aimed at examining the relationship between principal technology leadership practices as the exogenous (independent) variable and teacher ICT competency as the endogenous (dependent) variable. Thus, quantitative research method is applied to explain how one variable affects another (Creswell, 2014) or to establish relationship between variables (Fraenkel, Wallen, \& Hyun, 2011). This is a non-experimental quantitative research using survey technique through the administration of a set of questionnaires developed for data collection. A cross-sectional and self-administered questionnaire was the data collection tool for this research design. 


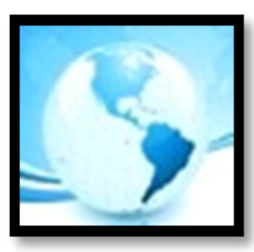

\section{Population and Sample of the Study}

The targeted population for this study consisted of all public secondary day school teachers in Negeri Sembilan, Malaysia. There are 6499 teachers within 89 schools located at six different districts in Negeri Sembilan. The minimum number of respondents needed for this study at the significance level $p=.05$ is 362 teachers (Krejcie \& Morgan, 1970). Sample selection for this study was conducted in several stages by probability sampling procedure which involved proportional stratified random sampling, simple random sampling and systematic random sampling. A total of 450 questionnaires were distributed to the respondents and a total of 417 questionnaires collected were analyzed, representing a valid response rate of $92.7 \%$.

\section{Instrumentation}

The data were collected using a set of questionnaires developed by the researcher. The instrument comprised of respondent demographic variables, principal technology leadership practices, and teacher ICT competency. Teacher demographic variables are gender, age group, teaching experience, highest educational level, and experience in using computer.

Principal technology leadership practice was measured based on the five composite dimensions of ISTE Standards•A(2009). The instrument was developed based on the elements in the ISTE Standards•A (2009) as guideline together with the adaptation of some High Impact Malaysian School Leaders Competencies Standard elements related to technology leadership from an instrument named "Instrumen Kompetensi Pemimpin Sekolah" (KOMPAS) which was developed by The National Institute of Educational Leadership and Management, Aminuddin Baki Institute(Senin, Manaf, Abd. Halim, \& Abd. Hamid, 2011). Teacher's perceptions on principal technology leadership practices on these five dimensions are measured according to a numerical rating scale. A numerical rating scale from number 0 to 10 is used to measure teachers' perception on principal technology leadership practices, where the first endpoint " $O$ " is anchored by the words "never practice at all" and the other endpoint " 10 " is anchored by the words "most frequent practice" (Johnson \& Christensen, 2008). The researcher chooses this numerical rating scale because it provides the highest level of measurement precision, permitting all mathematical operation to be performed (Hair, Black, Babin, \& Anderson, 2010).

Teacher ICT competency was measured according to ISTE Standards $\bullet$ T(2008). ISTE Standards $\bullet$ T is a standard for assessing the knowledge and skills which educators need to learn, work and teach in the digital world. This standard consist five dimensions which are: (i) Smart Pedagogy; (ii) Digital age learning experiences and assessments; (iii) Digital age work and learning; (iv) Digital citizenship and responsibility; and (v) Professional growth and leadership. Besides, the researcher also adapted some of the ICT competency standards for Malaysian Mathematics and Science teachers developed by a group of researchers using Delphi technique (Fong et al., 2013). The numerical rating scale from number 0 to 10 is used to measure teachers' level of competence. The first endpoint " $O$ " is anchored by the words "no competence at all" and the other endpoint " 10 " is anchored by the words "most competence".

The developed instrument was pilot tested using 57 secondary school teachers in some secondary schools located in the states of Selangor, Perak and Johor. Data gathered were analyzed using Statistical Packages for the Social Sciences (SPSS) version 22.0 for internal consistency. The results of analysis showed that the Cronbach alpha fell between .908-.944for the principal technology leadership practices dimensions, and in the range of .800-.929 for teacher ICT competency dimensions. These indicated that the instrument achieved a good level of internal consistency reliability. 


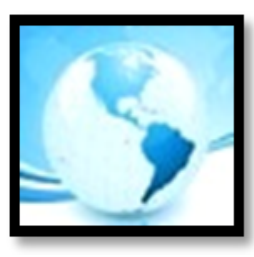

\section{MALAYSIAN ONLINE JOURNAL OF EDUCATIONAL MANAGEMENT (MOJEM)}

\section{Data Collection Procedure}

The data collection is carried out through direct administration and self-collection method. A formal letter was sent to the related schools to obtain permission from the principals to enter the site and to study their setting. On the data collection appointment date with a school, the researcher first meet with the respective school principal and obtained the principal's permission to get the school staff list. Then, the respondents were selected using systematic random sampling procedure. The selected respondents were informed to gather at one location and prior to the administration of the instrument, participants were briefed on the purpose of this study, told of their rights to withdraw from the study before, during or after they had completed the questionnaire and informed that their participation was voluntary and confidentiality was assured to alleviate teacher anonymity concerns. The respondents were given 20 minutes to fill up their responses on the provided questionnaires and immediately the questionnaires were collected by the researcher upon completion.

\section{Analysis of Data}

Numerical data gathered were analyzed quantitatively using SPSS and Analysis of Moment Structures (AMOS) version 22.0. Both descriptive and inferential statistical methods were used to analyze the data to answer the proposed research questions. Descriptive statistics in terms of mean and standard deviation are used to answer the first two research questions. The composite mean for each dimension was collapsed into three levels with equal interval where $0.00-3.33$ is interpreted as low; 3.34 to 6.67 as medium; and 6.68 to 10.00 as high. Inferential statistics in terms of Pearson product-moment correlation test was performed to examine the relationship between principal technology leadership practices and teacher ICT competency. Inferential statistic in terms of multiple regression analysis was carried out to identify which of the principal technology leadership practices dimensions contribute to changes in teacher ICT competency. Finally, Structural Equation Modelling (SEM) procedure with AMOS was carried out to evaluate whether the data collected fit with the proposed model of principal technology leadership practices and teacher ICT competency in Negeri Sembilan secondary schools.

\section{FINDINGS}

This section presents the results of the study according to each research question.

\section{Research Question 1:}

What are the levels of teacher ICT competency in Negeri Sembilan secondary schools?

Descriptive statistic was used to analyze the data collected from 417 teachers in Negeri Sembilan secondary schools. The analysis yield results as shown in Table 1.

Table 1

Mean, Standard Deviation and the Level of Teacher ICT Competency $(N=417)$

\begin{tabular}{|c|c|c|c|c|c|}
\hline \multicolumn{3}{|c|}{ Dimension } & \multirow{2}{*}{$\begin{array}{c}\text { Mean } \\
7.42\end{array}$} & \multirow{2}{*}{$\begin{array}{c}S D \\
1.19\end{array}$} & \multirow{2}{*}{$\begin{array}{l}\text { Leve } \\
\text { High }\end{array}$} \\
\hline 1) & Smart Pedagogy & & & & \\
\hline 2) & Digital Age Learning Experience and Assessments & & 7.28 & 1.21 & High \\
\hline 3) & Digital Age Work and Learning & & 7.39 & 1.14 & High \\
\hline 4) & Digital Citizenship and Responsibility & & 7.19 & 1.23 & High \\
\hline \multirow[t]{2}{*}{ 5) } & Professional Growth and Leadership & & 6.87 & 1.21 & High \\
\hline & & Overall & 7.19 & 1.08 & High \\
\hline
\end{tabular}

Based on Table 1, the overall mean for teacher ICT competency is 7.19. This could be interpreted as high level of teacher ICT competency in Negeri Sembilan secondary schools. The results of the analysis for each of the teacher ICT competency dimensions indicated that three out of the five teacher ICT competency dimensions have higher mean than the overall mean. 


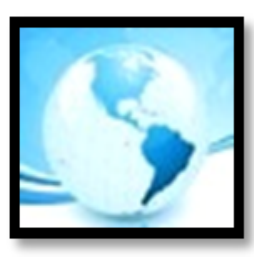

\section{MALAYSIAN ONLINE JOURNAL OF EDUCATIONAL MANAGEMENT (MOJEM)}

These dimensions are Smart Pedagogy, Digital Age Learning Experience and Assessments, and Digital Age Work and Learning. Digital Citizenship and Responsibility dimension has similar mean as the overall mean of teacher ICT competency. While the other dimension, Professional Growth and Leadership showed lower mean than the overall mean of teacher ICT competency. However, all the five teacher ICT competency dimensions have means that are interpreted as high level. These meant that the respondents rated themselves as demonstrating high level of competency for all the five teacher ICT competency dimensions in Negeri Sembilan secondary schools.

The first dimension, smart pedagogy comprised six items. The means and standard deviations for all the six items are showed in Table 2.

Table 2

\begin{tabular}{|c|c|c|c|}
\hline Item & Description & Mean & $S D$ \\
\hline D1 & I use ICT to promote students' creative and innovative thinking. & 7.72 & 1.33 \\
\hline D2 & I use ICT to engage students in exploring real-world issues. & 7.50 & 1.36 \\
\hline D4 & I use ICT to promote student reflection on learning. & 7.44 & 1.40 \\
\hline D3 & I use ICT to engage students in solving authentic problems. & 7.41 & 1.37 \\
\hline D5 & I use ICT to clarify learning processes for students. & 7.37 & 1.43 \\
\hline \multirow[t]{2}{*}{ D6 } & I use ICT to engage in knowledge construction with school community. & 7.08 & 1.36 \\
\hline & Overall Mean & 7.42 & 1.19 \\
\hline
\end{tabular}

From the results of descriptive analysis for each of the items shown in Table 2, three items have higher mean than the overall mean of smart pedagogy dimension. These three items are D1, D2, and D4. These indicated that the respondents rated themselves as being very competent in using ICT to promote students' creative and innovative thinking; to engage students in exploring real-world issues; and to promote student reflection on learning.

The second dimension, digital age learning experience and assessment dimension comprised six items. The means and standard deviations for all the six items are arranged in Table 3.

Table 3

Mean and Standard Deviation for Each of the Items in Digital Age Learning Experiences and Assessments Dimension $(N=417)$

\begin{tabular}{|c|c|c|c|}
\hline Item & Description & Mean & $S D$ \\
\hline D12 & $\begin{array}{l}\text { I use ICT to provide students with varied assessments (formative, summative, } \\
\text { etc.). }\end{array}$ & 7.39 & 1.42 \\
\hline D7 & I use ICT to share relevant learning experiences with students. & 7.33 & 1.38 \\
\hline D10 & $\begin{array}{l}\text { I use ICT to customize learning activities to address students' diverse learning } \\
\text { styles. }\end{array}$ & 7.30 & 1.31 \\
\hline D9 & I use ICT to develop technology-enriched learning environments. & 7.25 & 1.38 \\
\hline D11 & I use ICT to construct appropriate learning activities with students' ICT capabilities. & 7.20 & 1.43 \\
\hline \multirow[t]{2}{*}{ D8 } & I use ICT to adapt relevant learning experiences for students. & 7.18 & 1.35 \\
\hline & Overall Mean & 7.28 & 1.21 \\
\hline
\end{tabular}

Table 3 shows that three out of six items have higher mean than the overall mean of digital age learning experience and assessment dimension. These items are D12, D7, and D10. These indicated that the respondents rated themselves as highly competent in using ICT to provide students with varied assessments (formative, summative, etc.); to share relevant learning experiences with students; andto customize learning activities to address students' diverse learning styles. 


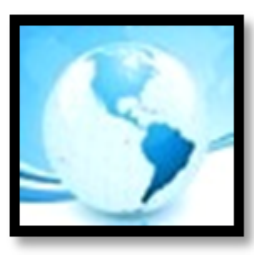

The third dimension, digital age work and learning comprised five items. The means and standard deviations for all the five items are presented in Table 4.

Table 4

Mean and Standard Deviation for Each of the Items in Digital Age Work and Learning Dimension $(N=417)$

\begin{tabular}{|c|c|c|c|}
\hline Item & Description & Mean & $S D$ \\
\hline D17 & $\begin{array}{l}\text { I use ICT to facilitate learning process (e.g., locate, analyze, evaluate information } \\
\text { etc). }\end{array}$ & 7.64 & 1.31 \\
\hline D16 & I use ICT to facilitate research process (e.g., locate information, analyze data etc). & 7.41 & 1.50 \\
\hline D15 & I use ICT to communicate effectively with school community. & 7.39 & 1.39 \\
\hline D14 & I use ICT to collaborate with school community to support student success. & 7.31 & 1.30 \\
\hline \multirow[t]{2}{*}{ D13 } & I use ICT to demonstrate fluency in new technology knowledge. & 7.21 & 1.38 \\
\hline & Overall Mean & 7.39 & 1.14 \\
\hline
\end{tabular}

Table 4, shows that two out of five items in the digital age work and learning dimension have higher mean than the overall mean of digital age work and learning dimension. These items are D17 and D16. These indicated that the respondents are highly competent in using ICT to facilitate the learning process (i.e., locate, analyze, evaluate information etc.) and research process (i.e., locate information, analyze data etc.). Besides, item D15 that has similar mean with the overall mean of digital age work and learning indicated that the respondents are able to communicate effectively with school community using ICT.

The fourth dimension, digital citizenship and responsibility, comprised five items. The means and standard deviations for all the five items are showed in Table 5.

Table 5

Mean and Standard Deviation for Each of the Items in Digital Citizenship and Responsibility Dimension ( $N=417)$

\begin{tabular}{|c|c|c|c|}
\hline Item & Description & Mean & $S D$ \\
\hline D19 & I use ICT to address diverse needs of learners by using learner-centered strategies. & 7.39 & 1.36 \\
\hline D18 & I use ICT to promote policies for legal and ethical ICT usage to my students. & 7.36 & 1.35 \\
\hline D20 & I use ICT to promote responsible social interactions. & 7.27 & 1.45 \\
\hline D21 & $\begin{array}{l}\text { I use ICT to develop cultural understanding with school community of other } \\
\text { cultures. }\end{array}$ & 7.00 & 1.45 \\
\hline \multirow[t]{2}{*}{ D22 } & I use ICT to develop global awareness with school community of other cultures. & 6.91 & 1.45 \\
\hline & $\begin{array}{ll}2 & \text { Overall Mean }\end{array}$ & 7.19 & 1.23 \\
\hline
\end{tabular}

Based on Table 5, three items have higher mean than the overall mean of digital citizenship and responsibility dimension. These items are D19, D18, and D20. These indicated that the respondents rated themselves as highly competent in using ICT to address diverse needs of learners by using learner-centered strategies; to promote policies for legal and ethical ICT usage to their students; andto promote responsible social interactions. However, the respondents rated lower mean than the overall mean of digital citizenship and responsibility dimension for item D21and D22. These indicated that the respondents are less competent in using ICT to develop cultural understanding and global awareness with school community of other cultures compared with the other ICT competencies in the digital citizenship and responsibility dimension. 


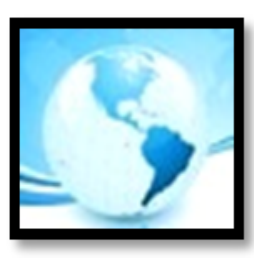

The fifth dimension, professional growth and leadership comprised nine items. The means and standard deviations for all the nine items are arranged in Table 6.

Table 6

Mean and Standard Deviation for Each of the Items in Professional Growth and Leadership Dimension (N=417)

\begin{tabular}{|c|c|c|c|}
\hline Item & Description & Mean & $S D$ \\
\hline D31 & I use ICT to enhance the teaching profession of my school community. & 7.25 & 1.46 \\
\hline D27 & I use ICT to participate in school community building. & 7.10 & 1.41 \\
\hline D29 & I use ICT to evaluate on effective ICT usage practices in student learning. & 6.99 & 1.45 \\
\hline D23 & $\begin{array}{l}\text { I use ICT to participate in local learning communities to explore creative teaching } \\
\text { and learning applications. }\end{array}$ & 6.90 & 1.45 \\
\hline D28 & I use ICT to develop other teacher's technology skills. & 6.85 & 1.45 \\
\hline D30 & I use ICT to reflect on effective ICT usage practices in student learning. & 6.84 & 1.46 \\
\hline D26 & I use ICT to participate in shared decision making. & 6.68 & 1.52 \\
\hline D24 & $\begin{array}{l}\text { I use ICT to participate in global learning communities to explore creative } \\
\text { teaching and learning applications. }\end{array}$ & 6.65 & 1.50 \\
\hline \multirow[t]{2}{*}{ D25 } & I use ICT to demonstrate vision of technology infusion. & 6.59 & 1.38 \\
\hline & Overall Mean & 6.87 & 1.21 \\
\hline
\end{tabular}

Table 6 shows that four out of nine items in the professional growth and leadership dimension (D31, D27, D29, and D23) have higher mean than the overall mean of professional growth and leadership dimension. This indicated that the respondents rated themselves as highly competent in using ICT to enhance the teaching profession of their school community; to participate in school community building; to evaluate on effective ICT usage practices in student learning; andto participate in local learning communities to explore creative teaching and learning applications. However, the respondents rated lower mean than the overall mean of professional growth and leadership dimension for item D26, D24, and D25. These indicated that the respondents are less competent in using ICT to participate in shared decision making; to participate in global learning communities to explore creative teaching and learning applications; andto demonstrate vision of technology infusion compared with the other ICT competencies in the professional growth and leadership dimension.

Overall, the data indicated that teachers in Negeri Sembilan secondary schools showed high level of ICT competency. Besides, these teachers also demonstrated high level of ICT competency for all the five dimensions of teacher ICT competency. The highest mean was smart pedagogy dimension, followed by digital age work and learning, digital age learning experience and assessments, digital citizenship and responsibility, and the lowest mean was for professional growth and leadership dimension.

\section{Research Question 2}

What are the levels of principal technology leadership practices in Negeri Sembilan secondary schools?

The descriptive analysis yield results as shown in Table 7.From Table 7, the overall mean of principal technology leadership practices is 7.15. This could be interpreted that majority of the respondents perceived that their principals demonstrated high level of principal technology leadership practices in Negeri Sembilan secondary schools. Two out of the five principal technology leadership practices dimensions have higher mean than the overall mean. These dimensions are Digital Age Learning Culture, and Visionary Leadership. 


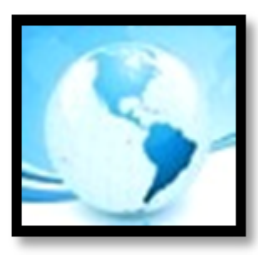

The other three principal technology leadership dimensions have lower mean than the overall mean: Digital Citizenship, Excellence in Professional Practice, and Systemic Improvement. However, all the five principal technology leadership practices dimensions have means interpreted as high level.

Table 7

Mean, Standard Deviation and the Level of Principal Technology Leadership Practices (N=417)

\begin{tabular}{lccc}
\hline Dimension & Mean & SD & Level \\
\hline 1) Visionary Leadership & 7.22 & 1.32 & High \\
2) Digital Age Learning Culture & 7.30 & 1.35 & High \\
3) Excellence in Professional Practice & 7.09 & 1.33 & High \\
4) Systemic Improvement & 7.07 & 1.35 & High \\
5) Digital Citizenship & 7.10 & 1.37 & High \\
& & $\mathbf{1 . 2 6}$ & High \\
\hline
\end{tabular}

Subsequently, the researcher would present the means and standard deviations for each of the items according to each principal technology leadership practices dimensions. The first dimension, visionary leadership comprised five items. The means and standard deviations for all the five items are showed in Table 8.

Table 8

Mean and Standard Deviation for Each of the Items in Visionary Leadership Dimension ( $N=417)$

\begin{tabular}{|c|c|c|c|}
\hline Item & Description & Mean & S.D. \\
\hline B5 & $\begin{array}{l}\text { My principal advocates various activities to support implementation of } \\
\text { technology-infused strategic plans. }\end{array}$ & 7.34 & 1.46 \\
\hline B1 & My principal leads the development of a shared vision that maximizes ICT usage. & 7.27 & 1.50 \\
\hline B4 & $\begin{array}{l}\text { My principal promotes participation of school community in planning technology- } \\
\text { infused strategic plans. }\end{array}$ & 7.25 & 1.51 \\
\hline B2 & My principal participates in the implementation of technology strategic plans. & 7.18 & 1.51 \\
\hline \multirow[t]{2}{*}{ B3 } & $\begin{array}{l}\text { My principal delivers comprehensive information about technology strategic } \\
\text { plans. }\end{array}$ & 7.05 & 1.57 \\
\hline & $\begin{array}{ll}2 & \text { Overall Mean }\end{array}$ & 7.22 & 1.32 \\
\hline
\end{tabular}

From the results of descriptive analysis for each of the items shown in Table 8, three items have higher mean than the overall mean of the visionary leadership dimension. These three items are B5, B1, and B4. This indicated that the respondents perceived that their principals lead the development of a shared vision that maximizes ICT usage in their school, advocate various activities to support the implementation of technology-infused strategic plans, and promote participation of school community in planning technology-infused strategic plans.

The second dimension, digital age learning culture comprised six items. The means and standard deviations for all the six items are presented in Table 9 below: 
Table 9

Mean and Standard Deviation for Each of the Items in Digital Age Learning Culture Dimension ( $N=417)$

\begin{tabular}{|c|c|c|c|}
\hline Item & Description & Mean & $S D$ \\
\hline B7 & My principal promotes effective use of ICT for learning. & 7.92 & 1.44 \\
\hline B9 & My principal ensures effective practice in ICT usage across the curriculum. & 7.30 & 1.55 \\
\hline B10 & $\begin{array}{l}\text { My principal promotes participation in learning communities that stimulate } \\
\text { innovation and creativity. }\end{array}$ & 7.27 & 1.51 \\
\hline B6 & $\begin{array}{l}\text { My principal ensures instructional innovation focused on continuous improvement } \\
\text { of digital-age learning. }\end{array}$ & 7.25 & 1.49 \\
\hline B11 & $\begin{array}{l}\text { My principal promotes participation in learning communities that stimulate digital } \\
\text { age collaboration. }\end{array}$ & 7.16 & 1.52 \\
\hline \multirow[t]{2}{*}{ B8 } & $\begin{array}{l}\text { My principal provides technology learner-centered environments to meet diverse } \\
\text { needs of learners. }\end{array}$ & 6.88 & 1.65 \\
\hline & $\begin{array}{cc}2 & \text { Overall Mean }\end{array}$ & 7.30 & 1.35 \\
\hline
\end{tabular}

Based on Table 9, only one item has much higher mean than the overall mean of digital age learning culture dimension. This is item B7 indicating that the respondents perceived that their principals promote effective use of ICT for learning in their school. However, item B8 has the lowest mean in the digital age learning culture dimension. This means that the respondents perceived their principals do not provide a technology learnercentered environment to meet diverse needs of learners.

The third dimension, excellence in professional practice comprised seven items. The means and standard deviations for all the seven items are arranged in the following Table 10.

Table 10

Mean and Standard Deviation for Each of the Items in Excellence in Professional Practice Dimension ( $N=417)$

\begin{tabular}{|c|c|c|c|}
\hline Item & Description & Mean & $S D$ \\
\hline B17 & $\begin{array}{l}\text { My principal stays abreast of emerging trends regarding effective use of } \\
\text { technology. }\end{array}$ & 7.31 & 1.56 \\
\hline B15 & My principal models effective communication among school community using ICT. & 7.17 & 1.49 \\
\hline B16 & My principal promotes effective collaboration among school community using ICT. & 7.17 & 1.45 \\
\hline B18 & $\begin{array}{l}\text { My principal encourages evaluation of new technologies potential to improve } \\
\text { student learning. }\end{array}$ & 7.16 & 1.51 \\
\hline B13 & $\begin{array}{l}\text { My principal facilitates learning communities in ICT usage among school } \\
\text { community. }\end{array}$ & 7.05 & 1.44 \\
\hline B14 & My principal participates in ICT usage learning communities. & 6.96 & 1.55 \\
\hline \multirow[t]{2}{*}{ B12 } & $\begin{array}{l}\text { My principal allocates resources (time, facilities, etc.) to ensure teacher ongoing } \\
\text { professional development in ICT fluency. }\end{array}$ & 6.78 & 1.60 \\
\hline & Overall Mean & 7.09 & 1.33 \\
\hline
\end{tabular}

Table 10 showed that four out of seven items (B17, B15, B16, and B18) in excellence in professional practice dimension have higher mean than the overall mean of excellence in professional practice dimension. This indicated that the respondents perceived their principals stay abreast of emerging trends regarding effective use of technology; model and promote effective communication and collaboration among school community using ICT; and encourage evaluation of new technologies potential to improve student learning. However, item B12 showed lower mean than the overall mean of excellence in professional practice dimension. 


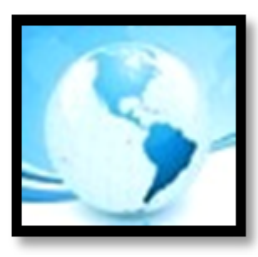

This indicated that the respondents perceived that their principals do not allocate enough resources (time, facilities, etc.) to ensure teacher ongoing professional development in ICT fluency. The fourth dimension, systemic improvement comprised six items. The means and standard deviations for all the six items are shown in Table 11.

Table 11

Mean and Standard Deviation for Each of the Items in Systemic Improvement Dimension ( $N=417)$

\begin{tabular}{|c|c|c|c|}
\hline Item & Description & Mean & $S D$ \\
\hline B21 & $\begin{array}{l}\text { My principal collaborates with various parties (school communities, other } \\
\text { academicians, etc.) to improve students' learning. }\end{array}$ & 7.50 & 1.44 \\
\hline B20 & $\begin{array}{l}\text { My principal collaborates with various parties (school communities, other } \\
\text { academicians, etc.) to improve staff performance. }\end{array}$ & 7.40 & 1.50 \\
\hline B19 & $\begin{array}{l}\text { My principal leads purposeful change to maximize the achievement of learning } \\
\text { goals through appropriate use of ICT resources. }\end{array}$ & 7.19 & 1.45 \\
\hline B23 & $\begin{array}{l}\text { My principal leverages strategic partnerships to support systemic } \\
\text { improvement. }\end{array}$ & 6.97 & 1.55 \\
\hline B24 & $\begin{array}{l}\text { My principal provides a robust infrastructure for the use of ICT to support } \\
\text { school operation. }\end{array}$ & 6.79 & 1.67 \\
\hline \multirow[t]{2}{*}{ B22 } & $\begin{array}{l}\text { My principal invites highly technology competent personnel to advance } \\
\text { school's ICT goal. }\end{array}$ & 6.58 & 1.88 \\
\hline & $\begin{array}{ll}2 & \text { Overall Mean }\end{array}$ & 7.07 & 1.35 \\
\hline
\end{tabular}

Based on Table 11, three out of six items recorded higher mean than the overall mean of systemic improvement dimension. These items are item B21, B20, and B19. This indicated that the respondents perceived their principals are able to lead purposeful change to maximize the achievement of learning goals through appropriate use of ICT resources; collaborate with various parties (school communities, other academicians, etc.) to improve student learning and staff performance. However, the lowest mean for item B22 indicated that the respondents perceived that their principals do not demonstrate very high practices in inviting highly technology competent personnel to advance the school's ICT goal.

The last dimension, digital citizenship comprised eight items. The means and standard deviations for all the eight items are displayed in Table 12.

Table 12

Mean and Standard Deviation for Each of the Items in Digital Citizenship Dimension ( $N=417)$

\begin{tabular}{llcc}
\hline Item & Description & Mean & SD \\
\hline B26 & My principal promotes legal and ethical ICT usage. & 7.58 & 1.49 \\
B29 & My principal promotes responsible social interactions related to the ICT usage. & 7.28 & 1.45 \\
B27 & My principal models legal and ethical ICT usage. & 7.24 & 1.65 \\
B28 & My principal establishes policies for legal and ethical ICT usage. & 7.10 & 1.59 \\
B30 & My principal models responsible social interactions related to ICT usage. & 7.04 & 1.49 \\
B31 & My principal models a shared cultural understanding through the use of ICT. & 6.98 \\
B32 & My principal facilitates the development of a shared cultural understanding & 6.97 & 1.48 \\
& through the use of ICT. & 6.50 \\
B25 & My principal ensures equitable access to digital tools and resources to meet & 1.73 \\
& learner needs. & Overall Mean & $\mathbf{7 . 1 0}$ \\
\end{tabular}


Table 12 shows that three out of eight items in the digital citizenship dimension have higher mean than the overall mean of digital citizenship dimension. These items are B26, B29, andB27. These indicated that the respondents perceived that their principals promote, and model, legal and ethical ICT usage; and promote responsible social interactions related to ICT usage. However, the lowest mean for item B25 indicated that respondents perceived their principals as not ensuring equitable access of digital tools and resources to meet the learner needs.

In conclusion, teachers in Negeri Sembilan secondary schools perceived that their principals practice high level of technology leadership. Furthermore, the data showed that all the five dimensions of principal technology leadership practices are at the high levels. These principals demonstrated highest practices in digital age learning culture dimension, followed by visionary leadership, digital citizenship, excellence in professional practice, and the lowest mean was for the systemic improvement dimension.

\section{Research Question 3}

Is there a significant relationship between principal technology leadership practices and teacher ICT competency in Negeri Sembilan secondary schools?

The Pearson product-moment correlation test was performed to examine the relationship between principal technology leadership practices and teacher ICT competency. Prior to the analysis, researchers need to compute the mean for principal technology leadership practices and the mean for teacher ICT competency using SPSS. Then, the correlation analysis was performed by comparing the means of these two variables. The result of the analysis is presented in Table 13.

Table 13

Pearson Product-Moment Correlation Analysis between Principal Technology Leadership Practices and Teacher ICT Competency

\begin{tabular}{llc}
\hline Variable & & Teacher ICT Competency \\
\hline Principal $\quad$ Technology & Pearson Correlation & $.590^{* *}$ \\
Leadership Practices & Sig. (2-tailed) & .000 \\
& $\mathrm{~N}$ & 417 \\
\hline
\end{tabular}

**. Correlation is significant at the .01 level (2-tailed)

Table 13 shows that for the sample of this study $(n=417)$, there is a statistically significant positive correlation which is moderately strong $(r=.590, p<.01)$ between principal technology leadership practices and teacher ICT competency in Negeri Sembilan secondary schools. This positive correlation revealed that if the principal practices higher level of technology leadership, the level of teacher ICT competency will be increased as well.

\section{Research Question 4}

Which of the principal technology leadership practices dimensions are the significant predictors of teacher ICT Competency in Negeri Sembilan secondary schools?

The multiple regression analysis yields outputs as shown in Table 14. 


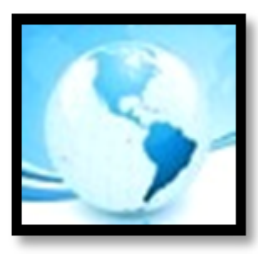

Table 14

Multiple Regression (Stepwise) on Principal Technology Leadership Practices to Teacher ICT Competency (N=417)

\begin{tabular}{lcccccc}
\hline Variable & (Unstad.) & (Stand.) & $\boldsymbol{t}$ & Sig & $\boldsymbol{R}^{\mathbf{2}}$ & \multicolumn{2}{c}{ Contribution } \\
& $\mathbf{B}$ & $\boldsymbol{\beta}$ & & & & (\%) \\
\hline Digital Citizenship & .300 & .382 & 4.655 & .000 & .350 & 35.0 \\
Systemic Improvement & .190 & .239 & 2.918 & .004 & .364 & 1.4 \\
Constant & 3.716 & & 16.12 & .000 & & \\
\hline
\end{tabular}

The result of multiple regression analysis shown in Table 14 indicates that the prediction model contained two out of the five predictors. These predictors are digital citizenship $(\beta=.382, p=.000<.05)$ and systemic improvement $(\beta$ $=.239$, and $p=.004<.05$ ). The digital citizenship dimension was found to contribute $35.0 \%$ of the variance on teacher ICT competency while the combination of digital citizenship and systemic improvement (model 2) accounted for $36.4 \%$ of variance on teacher ICT competency. These two models demonstrated large effect size on teacher ICT competency.

The dominant predictor for teacher ICT competency is digital citizenship dimension $(\beta=.382, t=4.655$ and $p=$ $.000)$. The $t$-test result was significant at the significance level of $p<.05$ with the $R^{2}=.350$, indicating that the digital citizenship dimension contributes $35.0 \%$ of variance on teacher ICT competency. Based on the standardized beta value, when the digital citizenship dimension increases by one unit of standard deviation, teacher ICT competency increases by .382 unit of standard deviation.

The second predictor which contributed only $1.4 \%$ of variance in teacher ICT competency is the systemic improvement dimension $(\beta=.239, t=2.918$ and $p=.004)$. The $t$-test result was significant at the significance level $p<$ .05 with the combined $R^{2}=.364$; this indicated that the systemic improvement dimension contributes $1.4 \%(36.4 \%$ $35.0 \%)$ of the variance in teacher ICT competency. Based on the standardized beta value, when the systemic improvement dimension increases by one unit of standard deviation, teacher ICT competency will increase by .239 unit of standard deviation.

Table 15

Multiple Regression Analysis (Stepwise): ANOVA

\begin{tabular}{lccccc}
\hline & Sum of Squares & df & Mean Square & $\boldsymbol{F}$ & Sig. \\
\hline Regression & 175.245 & 2 & 87.622 & 118.238 & .000 \\
Residual & 306.801 & 414 & .741 & & \\
Total & 482.046 & 416 & & & \\
\hline
\end{tabular}

Based on Table 15, the F-test result indicated a statistically significant relationship between the two predictor variables with teacher ICT competency $[F(2,414)=118.238, p=.000]$ at the significance level of $p<.05$. The multiple regression analysis results also show that the combination of the two dimensions of principal technology leadership practices namely digital citizenship and systemic improvement accounted for $36.4 \%$ of the variance in teacher ICT competency. This means that as much as $63.6 \%$ of the variance on teacher ICT competency is unable to be predicted by principal technology leadership practices as it may be caused by other variables (other factors) not examined in this study.

\section{Research Question 5}

Does the proposed model of principal technology leadership practices and teacher ICT competency fit with the data collected from Negeri Sembilan secondary schools teachers?

The main function of the model-testing procedure is to identify the goodness-of-fit between the proposed model and the data collected from the sample (Byrne, 2010). The analysis yielded results as presented in Figure 2 


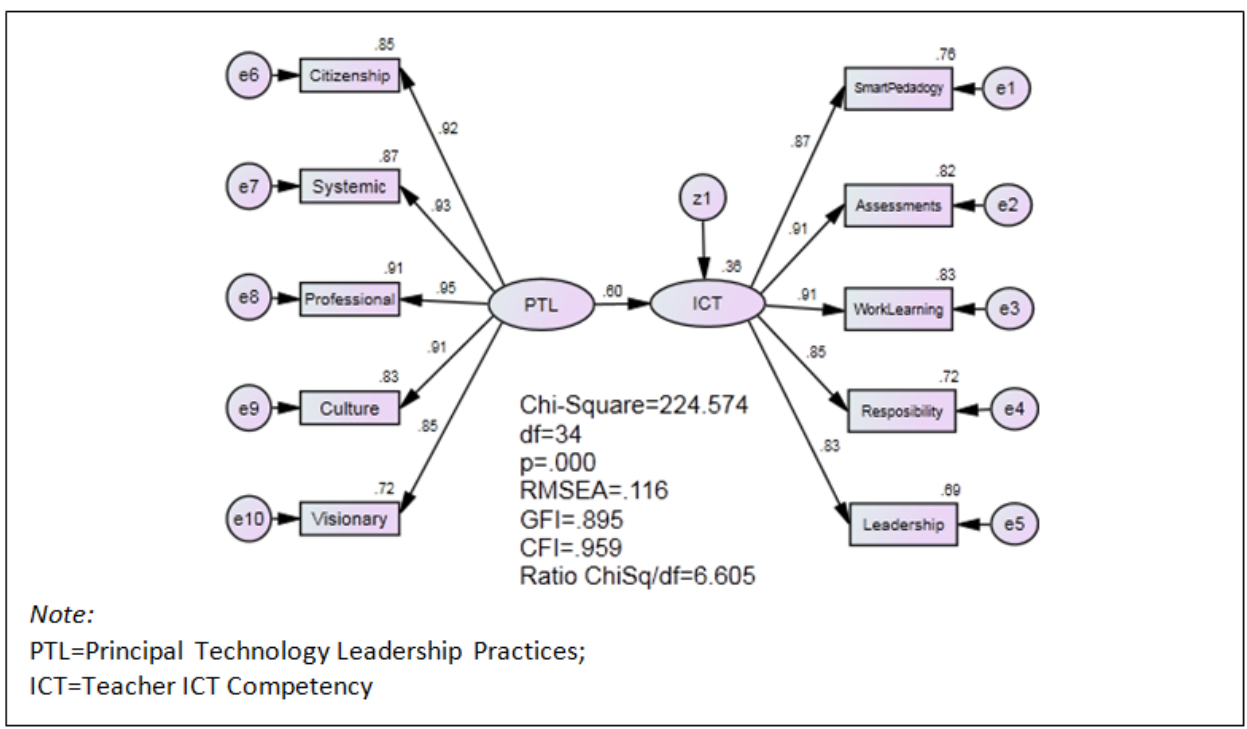

Figure 2: The Proposed Structural Model

Figure 2 indicated that the fitness indices of the proposed structural model does not achieve the level of fitness required for RMSEA, GFI, and Ratio Chisq/df. According to Byrne (2010), the re-specification procedure is the model-generating scenario is carried out to obtain a model that is both statistically well-fitting and substantively meaningful. Thus, based on the suggestion of the modification indices, a few of the measurement errors need to be set as "free parameter" to improve the model fitness. The measurement errors that need to be correlated are e1 with e2 and e9 with e10. The re-specified structural model is presented in Figure 3.

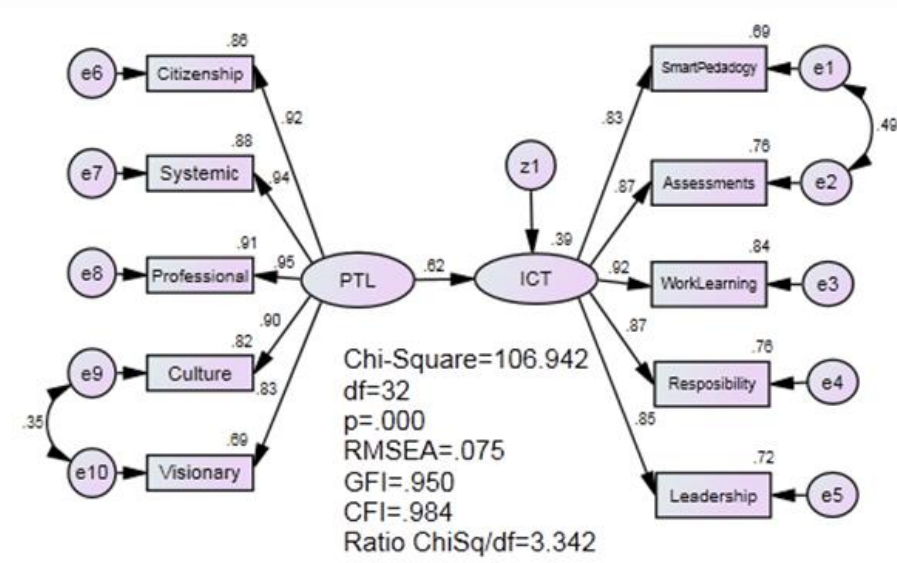

Note:

PTL=Principal Technology Leadership Practices; ICT $=$ Teacher ICT Competency

Figure 3.Re-Specified Structural Model 
Based on the re-specified structural model shown in Figure 3, it was found that all the fitness indices have achieved the threshold values. This indicated that the re-specified structural model fit with the data collected from Negeri Sembilan secondary schools. The standardized beta value for the PTL $\rightarrow$ ICT is .62, indicated that when principal technology leadership practices (PTL) increase by one standard deviation, teacher ICT competency (ICT) would increase .62 standard deviations. The squared multiple correlation for teacher ICT competency (ICT) is .389. This indicated that $38.9 \%$ of the variance in teacher ICT competency could be predicted by principal technology leadership practices. This means that as much as $61.1 \%$ of the variance in teacher ICT competency acceptance is unable to be predicted by principal technology leadership practices as it may be caused by other variables (other factors) not examined in this study.

\section{DISCUSSION}

Technology advancement is forcing teachers to engage with various types of technology in carrying out their routine teaching work (Prokopiadou, 2012; Teo, 2015). In order to be effective, teachers should strive to improve their pedagogical knowledge and instructional skills to enhance student learning. They should constantly adapt to new technologies and refine their knowledge, skills and competencies in order to integrate instructional technology efficiently and effectively (Pynoo et al., 2011). Teacher ICT competency is the driving force towards achieving the goals of technology integration into the classroom (Varol, 2013). Besides, teacher ICT competency can be viewed as a valuable national asset in terms of human resources which is important in promoting worldclass education as outlined in Vision 2020. The results of this study indicated that teachers in Negeri Sembilan secondary schools showed high level of ICT competency for all the five dimensions of teacher ICT competency. This finding aligned with those of Harin Hafian (2011), Tasir, Amin Abour, Abd Halim, and Harun (2012), and Umar and Mohd Yusoff (2014), indicating that Malaysian teachers demonstrated high level of ICT competency. The high level teacher ICT competency implies that various computer literacy training programs to enhance teacher ICT skills that have been implemented by the Malaysian government over these years were successful.

As technologies become increasingly important in educational systems and principals' role as technology leader have been identified as a way of supporting teachers' effective technology integration into the instructional process, we need to raise school administrators' understanding about their response and impact of these technological changes(Richardson et al., 2012). The major responsibility for principals who act as a school leaders is to initiate and implement school change through ICT usage and facilitate complex decisions to integrate IT into the instructional process and school administration (Afshari, Kamariah, Wong, Bahaman, \& Foo, 2008). The results of this study indicated that teachers in Negeri Sembilan secondary schools perceived that their principals practiced high level of technology leadership for all the five dimensions. This finding was in line with Alan Seay (2004) who found that the principals in Texas High School demonstrated a high mean score for all the ISTE Standards $\bullet A$ dimensions. Similar findings were also reported by Alkrdem (2014), Eren and Kurt (2011), Faridah (2011) and Moktar (2011). This finding reflected that principals in Negeri Sembilan secondary schools have realized their role as technology leaders and they are capable of playing a technology leadership role in their daily practices as observed by their teachers.

The Pearson product-moment correlation test showed that there is a statistically significant and moderately strong positive correlation between principal technology leadership practices and teacher ICT competency. 


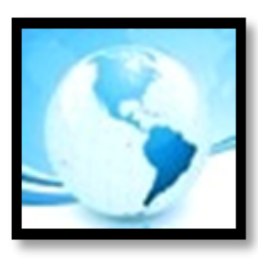

\section{MALAYSIAN ONLINE JOURNAL OF EDUCATIONAL MANAGEMENT (MOJEM)}

This positive correlation revealed that if the principal practices higher level of technology leadership, the level of teacher ICT competency will be increased as well. This finding confirmed that principal technology leadership practice is one of the factors influencing teacher ICT competency. The relationship that exist between principal technology leadership practices and teacher ICT competency could be supported by many leadership theories (Bass \& Bass, 2008; Bush, 2011; Leithwood \& Jantzi, 2006; Northouse, 2013; Owens \& Valesky, 2007; Robbin \& Judge, 2013; Yukl, 2013) showing that leadership is a process of influence through social interaction. In addition, Yukl (2013) portrayed that motivation is a typical type of leader influence to cause the subordinate to be more capable of performing the designated task. In order for teachers to be more capable of task performance, the leader should provide the required knowledge and skills. In the context of this study, principals need to provide teachers with ICT competency so that they can carry out their daily work with technology. This finding was further supported by the empirical study findings by Harin Hafian (2011) and Moktar (2011), who noted a significant relationship between principal technology leadership practices with teacher ICT competency.

Furthermore, based on the multiple regression analysis, digital citizenship and systemic improvement are the two principal technology leadership practices dimensions that are statistically significant predictors of teacher ICT competency in Negeri Sembilan secondary schools. This finding implies that the level of teacher ICT competency will be increased when teachers perceived that their principal concerns about social, ethical and legal issues regarding ICT usage among their school community are addressed and believed that using ICT could improve students' learning and staff performance.

The analysis of data showed that the proposed structural model does not achieve the level of fitness required for some of the fitness indices. This reflected that the proposed structural model does not fit well with the data collected from Negeri Sembilan secondary school teachers. Hence, a re-specified structural model, as shown in Figure 3 has been established.

\section{CONCLUSION}

Technology plays an important role in schools around the world. Teachers and administrators are using technology in some aspect of their daily activities. This study provides evidence that Malaysian principals and teachers are moving into the fourth wave of the Smart Schools Roadmap (2011-2020) which is the consolidation and stabilization phase according to the Policy on ICT in Education for Malaysia (Ministry of Education Malaysia, 2010) where technology usage has become an integral part of the nation's learning process.

There is a tremendous need for leadership in technology use to ensure that it makes a valuable and lasting contribution to education. Furthermore, this study revealed that principals who act as successful technology leaders should continuously strive to enhance teacher ICT competency. Besides, policy makers should design professional development programs to cultivate skills among principals for more effective and efficient utilization of technology for learning. 


\section{REFERENCES}

Adeyemi, T. O., \& Olaleye, F. O. (2010). Information Communication and Technology (ICT) for the effective management of secondary schools for sustainable development in Ekiti State, Nigeria. American-Eurasian Journal of Scientific Research, 5(2), 106-113.

Afshari, M., Kamariah, A. B., Wong, S. L., Bahaman, A. S., \& Foo, S. F. (2008). School leadership and Information Communication Technology. The Turkish Online Journal of Educational Technology, 7(4), 82-91.

Alan Seay, D. (2004). A study of the technology leadership of Texas high school principals. (Doctoral dissertation, University of North Texas, Denton). Retrieved from http://search.proquest.com/docview/305168558?accountid=28930

Alkrdem, M. (2014). Technological leadership Behavior of high school headteachers in Asir Region, Saudi Arabia. Journal of International Education Research, 10(2), 95-100.

Avci Yucel, U., \& Gulbahar, Y. (2013). Technology Acceptance Model: A review of the prior predictors.Journal of Faculty of Educational Science, Ankara University, 46(1), 89-109.

Bass, B. M., \& Bass, R. (2008). The Bass handbook of leadership: Theory, research, andmanagerial applications.New York, NY: Free Press.

Bolman, D. B. (2012). Examining the relationship between technology leadership behaviors and project success. Doctor of Philosophy Ph.D., Northcentral University, Ann Arbor. Retrieved from http://search.proquest.com/docview/1287814661 ?accountid=28930 ProQuest Dissertations \& Theses Global database. (3536047)

Bush, T. (2011). Theories of educational leadership and management (4th ed.). London: SAGE.

Byrne, B. M. (2010). Structural Equation Modeling With AMOS: Basic Concepts, Applications, and Programming(2nd ed.). New York, NY: Taylor \& Francis.

Chang, I.-H., Chin, J. M., \& Hsu, C.-M. (2008). Teachers' Perceptions of the Dimensions and Implementation of Technology Leadership of Principals in Taiwanese Elementary Schools. [Article]. Journal of Educational Technology \& Society, 11(4), 229-245.

Chen, L.-L. (2004). Pedagogical strategies to increase pre-service teachers' confidence in computer learning.Educational Technology \& Society, 7(3), 50-60.

Creswell, J. W. (2014). Educational research: Planning, conducting, and evaluating quantitative and qualitative research (4th ed.). Harlow, UK: Pearson.

Economic Planning Unit of Prime Minister's Department. (2010). Tenth Malaysia Plan 2011-2015. Putrajaya: Author.

Educational Policy Planning and Research Division. (2012). National Education Policy, Ministry of Education. Shah Alam, Selangor: Giga Wise Network. 
Eren, E. S., \& Kurt, A. A. (2011). Technological leadership behavior of elementary school principals in the process of supply and use of educational technologies. Education, 131(3), 625-636.

Faridah, J. (2011). Technology leadership of school administrators in High Performing Schools. (Unpublished Master's thesis, The National University of Malaysia, Bangi).

Flanagan, L., \& Jacobsen, M. (2003). Technology leadership for the twenty-first century principal. Journal of Educational Administration, 41(2), 124-142.

Fong, S. F., Ch'ng, P. E., \& Por, F. P. (2013). Development of ICT Competency Standard Using the Delphi Technique. Procedia - Social and Behavioral Sciences, 103, 299-314.

Fraenkel, J., Wallen, N., \& Hyun, H. (2011). How to design and evaluate research in education (8th ed.). New York, NY: McGraw-Hill.

Hair, J. F., Black, W. C., Babin, B. J., \& Anderson, R. E. (2010). Multivatiate data analysis(7th ed.). Upper Saddle River, NJ: Prentice Hall.

Hamsha, I. (2011). Evaluation of Multimedia Super Corridor (MSC Malaysia) contribution in Malaysia economy. (Master of Science, Ritsumeikan Asia Pacific University).

Harin Hafian, R. (2011). Principals' transformational leadership on teachers' computer literacy in a Vocational Secondary School, Selangor. (Unpublished Master's thesis, University of Malaya, Kuala Lumpur).

Haughey, M. (2006). The impact of computers on the work of the principal: Changing discourses on talk, leadership and professionalism. School Leadership \& Management, 26(1), 23-36. doi: 10.1080/13634230500492897

Haydn, T., \& Barton, R. (2008). 'First do no harm': Factors influencing teachers' ability and willingness to use their subject teaching. Computer \& Education, 51, 439-447.

House, R. J. (1971). A Path Goal Theory of leader effectiveness.Adminstrative Science Quarterly, 16(3), $321-339$.

House, R. J. (1996). Path-Goal Theory of leadership: Lessons, legacy, and areformulated theory.Leadership Quarterly, 7(3), 323-352.

International Society for Technology in Education. (2008). ISTE Standards for Teachers.

International Society for Technology in Education. (2009). ISTE Standards Administrators.

Johnson, B., \& Christensen, L. (2008). Educational research: Quantitative, qualitative, and mixed approaches(3rd ed.). Thousand Oaks, CA: SAGE.

Krejcie, R. V., \& Morgan, D. W. (1970). Determining sample size for research activities.Educational And Psychological Measurement, 30, 607-610.

LaFrance, J. A., \& Beck, D. (2014). Mapping the terrain:Educational leadership field experiences in K-12 virtual schools.Educational Administration Quarterly, 50(1), 160-189. 


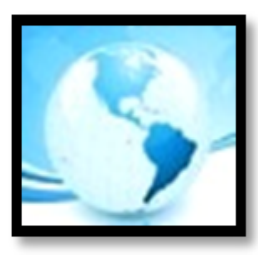

Leithwood, K., \& Jantzi, D. (2006). Transformational school leadership for large-scale reform: Effects on students, teachers, and their classroom practices. School Effectiveness and School Improvement, 17(2), 201-227.

Leong, M. W. (2010). Principal technology leadership and the level of ICT application of teachers at asecondary school in Seremban District. (Unpublished Master's thesis, University of Malaya, Kuala Lumpur).

Levin, J. A., \& Datnow, A. (2012). The principal role in data-driven decision making: Using case-study data to develop multi-mediator models of educational reform. School Effectiveness and School Improvement, 23(2), 179-201. doi: 10.1080/09243453.2011.599394

Liew, V. K. (2007). ICT in Education: An actionlearning approach using soft system methodology.Educational Management and Leadership, 17(2), 17-37.

Lu, H. Y. (2013). Technology integration and pedagogical innovations in Malaysia higher education institutions. (Unpublished doctoral dissertation, University of Malaya, Kuala Lumpur).

Mas Nida, M. K., Wong, S. L., \& Ayub, A. F. (2011). Enhancing teachers' professional development through laptops. In S. L. Wong, M. K. Mas Nida, S. Abu Daud \& T. Othman (Eds.), Technology \&education: Issues, empirical research and applications. Serdang: Universiti Putra Malaysia Press.

Ministry of Education Malaysia. (2010). Policy on ICT in Education Malaysia. Putrajaya, Malaysia: Author.

Ministry of Education Malaysia. (2012a). Executive Summary Malaysia Education Blueprint $2013-2025$ (Preschool to Post-Secondary Education). Putrajaya: Author.

Ministry of Education Malaysia. (2012b). Interim Strategic Plan 2011-2020. Putrajaya, Malaysia: Author..

Ministry of Education Malaysia. (2013). Malaysia Education Blueprint 2013-2025 (Preschool to Post-Secondary Education). Putrajaya, Malaysia: Author.

Ministry of Finance. (2014). Feedback on The Auditor General's Report, Series 3. Putrajaya: Author.

Moktar, J. (2011). Technology leadership and teachers' ICT competency in a religious secondary school in Kuching, Sarawak. (Unpublished Master's thesis, University of Malaya, Kuala Lumpur).

Neufeld, D. J., Dong, L., \& Higgins, C. (2007). Charismatic leadership and user acceptance of information technology. European Journal of Information Systems, 16(4),494-510.

Norazah, N., Yusma, Y., \& Kamaruzaman, J. (2010). A quantitative analysis of Malaysian secondary school technology leadership.Management Science and Engineering, 4(2), 124-130.

Northouse, P. G. (2013). Leadership: Theory and practice (6th ed.). Thousand Oaks, CA: SAGE.

Owens, R. G., \& Valesky, T. C. (2007). Organizational behavior in education: Adaptiveleadership and school reform (9th ed.).Boston, MA: Pearson.

Papa, R. (2011). Technology leadership for school improvement. Thousand Oaks, CA: SAGE.

Prokopiadou, G. (2012). Using Information and Communication Technologies in school administration: Researching Greek Kindergartenschools. Educational Management Administration \& Leadership, 40(3), 305-327. 
Pynoo, B., Devolder, P., Tondeur, J., van Braak, J., Duyck, W., \& Duyck, P. (2011). Predicting secondary school teachers' acceptance and use of a digital learning environment: A cross-sectional study. Computers in Human Behavior, 27, 568-575.

Richardson, J. W., Bathon, J., Flora, K. L., \& Lewis, W. D. (2012). NETS.A Scholarship: A Review of published literature.Journal of Research on Technology in Education, 45(2), 131-151.

Robbins, S. P., \& Judge, T. A. (2013). Organizational behavior (15th ed.).USA: Pearson.

Rossafri, M., \& Balakrishnan, M. (2007). Translating technology leadership to create excellent instructional leadership.Educational Leadership and Management Journal, 17(2), 91-103.

Sathiamoorthy, K., Leong, M. W., \& Mohd Jamil, S. (2011). Principal technology leadership and teachers' ICT applications in two different school settings in Malaysia. Paper presented at the International Conference on Application of ICT in economy and education (ICAICTEE), UNWE, Sofia, Bulgaia.

Sathiamoorthy, K., Sailesh, S., \& Zuraidah, A. (2012). Principal's strategies for leading ICT integration: The Malaysian perspective. Creative Education, 3, 111-115.

Senin, A., Manaf, A. R., Abd. Halim, R., \& Abd. Hamid, A. J. (2011). Instrumen Kompetensi Pemimpin Sekolah (KOMPAS). Genting Highlands: Institute Aminuddin Baki, Ministry of Education.

Tasir, Z., Amin Abour, K. M. E., Abd Halim, N. D., \& Harun, J. (2012). Relationship between teachers' ICT competency, confidence level, and satisfaction toward ICT training programmes: A case study among postgraduate students. Turkish Online Journal of Educational Technology, 11(1), 138-144.

Teo, T. (2015). Comparing pre-service and in-service teachers' acceptance of technology: Assessment of measurement invariance and latent mean differences. Computers \& Education, 83(0), 22-31. doi: 10.1016/j.compedu.2014.11.015

Trilling, B., \& Fadel, C. (2009). 21st Century skills: Learning for life in our times. New York, NY: Wiley.

Umar, I. N., \& Mohd Yusoff, M. T. (2014). A study on Malaysian teachers' level of ICT skills and practices, and its impact on teaching and learning. Procedia - Social and Behavioral Sciences, 116, 979-984.

Varol, F. (2013). Elementary school teachers and teaching with technology. The Turkish Online Journal of Educational Technology, 12(3), 85-90.

Wachira, P., \& Keengwe, J. (2011). Technology integration barriers: Urban school Mathematics teachers perspectives. Journal of Scientific Educational Technology, 20, 17-25.

Wahdain, E. A., \& Ahmad, M. N. (2014). User acceptance of Information Technology: Factors, theories and applications. Journal of Information Systems Research and Innovation, 6, 17-25.

Webber, C. F. (2003). Technology-mediated leadership development networks: Expanding educative possibilities. Journal of Educational Administration, 41(2), 201-218. 


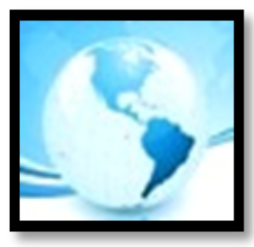

\section{MALAYSIAN ONLINE JOURNAL OF EDUCATIONAL MANAGEMENT (MOJEM)}

Wilmore, D., \& Betz, M. (2000). Information Technology and schools: The principal's role.Educational Technology \& Society, 3(4), 12-19.

Wong, S. L., Mas Nida, M. K., Abu Daud, S., \& Othman, T. (2011). Technology \& Education: Issues, empirical research and applications. Serdang: Universiti Putra Malaysia Press.

Yukl, G. (2013). Leadership in organizations (8th ed.). Upper Saddle River, NJ: Pearson. 